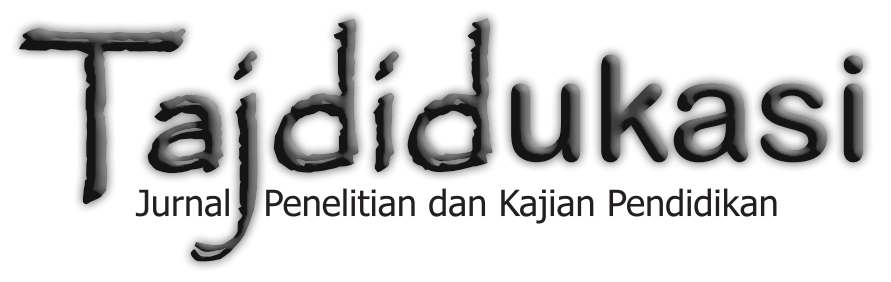




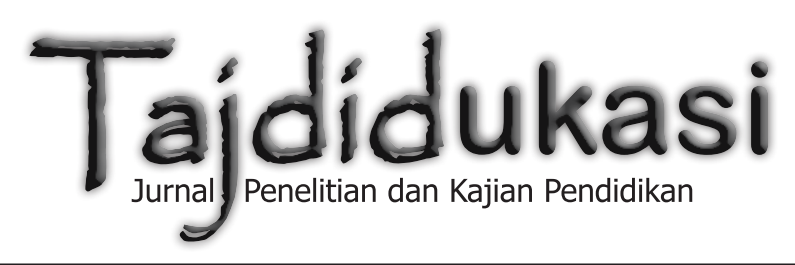

Volume VIII, No. 2, Juli 2018

ISSN: 1979-6943

Tajdidukasi: Jurnal Penelitian dan Kajian Pendidikan merupakan jurnal Penelitian dan Kajian Pendidikan yang berisi Penelitian Tindakan Kelas (PTK) dan Penelitian Tindakan Sekolah (PTS) serta Kajian Pendidikan interdisipliner di Perguruan Tinggi yang diterbitkan Majelis Pendidikan Dasar dan Menengah Pimpinan Wilayah Muhammadiyah Daerah Istimewa Yogyakarta. Artikel hasil PTK dan PTS serta kajian pemikiran pendidikan ditulis oleh para Guru dan Kepala Sekolah serta Dosen dalam mengujicobakan metode dan strategi pembelajaran untuk meningkatkan kualitas pendidikan baik SD/MI, SMP/MTs dan SMA/MA/SMK serta Perguruan Tinggi. Artikel PTK dan PTS fokus pada mata pelajaran di sekolah/madrasah, seperti Ilmu Pengetahuan Alam (IPA), Imu Pengetahuan Sosial (IPS), Matematika, Fisika, Kimia, bahkan teknik, seperti Teknik Mesin, Elektro, Informatika dan lain sebagainya. Sementara itu, artikel Kajian Pendidikan merupakan penelitian interdisipliner dan multidisipliner yang dilakukan Dosen di Perguruan Tinggi terhadap khasanah keIslaman.

Tajdidukasi: Jurnal Penelitian dan Kajian Pendidikan adalah jurnal terbuka yang versi softfile-nya bisa dibaca dan diakses secara gratis, sementara versi print out/ hardcopy dapat diperoleh dengan menghubungi distributor di alamat serial tajdidukasi.ac.id. Sof-file keseluruhan artikel yang diterbitkan dapat diakses melalui Tajdidukasi Open Access Juornal di www.dikdasmenpwmdiy.or.id

Pimpinan Editor
Suyadi, Universitas Ahmad Dahlan (UAD) Yogyakarta, Indonesia

Anggota Editor

Arif Budi Raharjo, Universitas Muhammadiyah Yogyakarta (UMY), Indonesia

Achmad Muhammad, UIN Sunan Kalijaga Yogyakarta, Indonesia

Hendro Widodo, Universitas Ahmad Dahlan (UAD) Yogyakarta

Mundzirin Yusuf, UIN Sunan Kalijaga Yogyakarta, Indonesia

Sumedi, UIN Sunan Kalijaga Yogyakarta, Indonesia

Sukamto, Universitas Muhammadiyah Yogyakarta (UMY), Indonesia

Sumarsono, UIN Sunan Kalijaga Yogyakarta Indonesia

Sarjilah (Lembaga Penjaminan Mutu Pendidikan) Yogyakarta

Fathur Rahman, M.Si., Universitas Negeri Yogyakarta (UNY) Indonesia

\section{Editor Pelaksana}

Suryanto, Universitas Muhammadiyah Yogyakarta (UMY), Indonesia

Suyatno, Universitas Ahmad Dahlan (UAD) Yogyakarta

Farid Setiawan, Universitas Ahmad Dahlan (UAD) Yogyakarta

Alamat Redaksi:

Kantor Majelis Pendidikan Dasar dan Menengah Pimpinan

Wilayah Muhammadiyah D.I. Yogyakarta

J1. Gedongkuning No. 130B Yogyakarta

Kode Pos : 55171

Telephone : (0274) 377078

Facsimile : (0274) 371718

Website : www.dikdasmenpwmdiy.or.id

E-Mail : tajdidukasi@dikdasmenpwmdiy.or.id 


\title{
IMPLEMENTASI MIND MAPPING DALAM \\ PEMBELAJARAN SEJARAH UNTUK \\ MENINGKATKAN HASIL BELAJAR SISWA DI \\ SMA MUHAMMADIYAH 3 YOGYAKARTA
}

\author{
Sri Mawanto \\ SMA Muhammadiyah 3 Yogyakarta \\ e-mail: srimawanto@yahoo.com
}

\begin{abstract}
Abstrak
Penelitian ini bertujuan untuk mengetahui implementasi Mind Mapping dalam meningkatkan hasil belajar siswa di SMA Muhammadiyah 3 Yogyakarta. Penelitian ini merupakan Penelitian Tindakan Kelas dengan subjek penelitian siswa kelas X IIS 1. Teknik pengumpulan data menggunakan, observasi, dokumentasi, dan tes. Hasil penelitian menunjukkan bahwa pada pra siklus nilai di bawah KKM sebanyak 28 siswa yang belum tuntas dengan persentase ketuntasan sebanyak $22,22 \%$. Setelah dikenai tindakan pada siklus 1 dengan menggunakan metode mind mapping maka jumlah siswa yang di bawah KKM mengalami penurunan dari 28 siswa menjadi 11 siswa. Sedangkan nilai yang diatas KKM mengalami kenaikan dari 8 siswa menjadi 25 siswa dengan persentase ketuntasan sebanyak 69,44\%. Setelah dikenai tindakan pada siklus 2 jumlah siswa yang di bawah KKM mengalami penurunan dari 11 siswa menjadi 4 siswa. Sedangkan nilai yang diatas KKM mengalami kenaikan dari 25 siswa menjadi 32 siswa dengan persentase ketuntasasan sebanyak $88,89 \%$. Ketuntasan hasil belajar siswa ini telah melampaui target penelitian yaitu sebesar $\geq 75 \%$. Dengan demikian, dapat disimpulkan bahwa implementasi Mind Mapping dapat meningkatkan hasil belajar siswa dalam pembelajaran mata pelajaran Sejarah di SMA Muhammadiyah 3 Yogyakarta.
\end{abstract}

Kata Kunci: Mind mapping, Hasil Belajar, pembelajaran sejarah

\section{A. PENDAhULUAN}

Pada umumnya model pembelajaran di sekolah saat ini masih bersifat konvensional yaitu pembelajaran yang berpusat pada guru sedangkan siswa sebagai objek yang hanya duduk diam dan mendengarkan apa yang disampaikan oleh guru. Model pembelajaran ini hanya menggerakkan otak kiri siswa untuk bekerja, yang berdampak pada rasa kebosanan dan kejenuhan siswa terhadap proses pembelajaran. Banyak cara untuk menciptakan proses pembelajaran yang kondusif, dimana para peserta didik dapat mengembangkan aktivitas dan kreativitas belajarnya secara optimal sesuai dengan kemampuannya masing-masing. Menurut Gibbs dalam Mulyasa (2002:106) mengatakan bahwa kretivitas dapat dikembangkan dengan memberi kepercayaan, komunikasi yang bebas, pengarahan diri dan pengawasan yang tidak terlalu ketat.

Menurut Slameto (2008:7-8) hasil belajar adalah sesuatu yang diperoleh 
dari suatu proses usaha setelah melakukan kegiatan belajar yang dapat diukur dengan menggunakan tes guna melihat kemajuan siswa. Selanjutnya, hasil belajar diukur dengan rata-rata hasil tes yang diberikan dan tes hasil belajar itu sendiri adalah sekelompok pertanyaan atau tugas-tugas yang harus dijawab atau diselesaikan oleh siswa dengan tujuan mengukur kemajuan belajar siswa. Menurut Mudjijo (1995:29) tes hasil belajar bermaksud untuk mengukur sejauh mana para siswa telah menguasai atau mencapai tujuan-tujuan pengajaran yang telah ditetapkan.

Menurut Sanjaya (2009:127-128) pada umumnya hasil belajar dapat dikelompokkan menjadi tiga ranah, yaitu: (1) Ranah kognitif, adalah tujuan pendidikan yang berhubungan dengan kemampuan intelektual atau kemampuan berpikir, seperti kemampuan mengingat dan kemampuan memecahkan masalah. Domain kognitif menurut Bloom terdiri dari enam tingkatan yaitu pengetahuan, pemahaman, aplikasi, analisis, sintesis, dan evaluasi; (2) Ranah afektif, berkenaan dengan sikap, nilai-nilai, dan apresiasi. Ada lima tingkatan dalam ranah afektif ini yaitu penerimaan, merespons, menghargai, organisasi, dan pola hidup; dan (3) Ranah psikomotor, meliputi semua tingkah laku yang menggunakan syaraf dan otot badan. Ada lima tingkatan dalam ranah ini, yaitu imitasi, manipulasi, presisi, artikulasi, dan naturalisasi.

Berdasarkan konsepsi tersebut, pengertian hasil belajar dapat disimpul- kan sebagai perubahan perilaku secara positif serta kemampuan yang dimiliki siswa dari suatu interaksi tindak belajar dan mengajar yang berupa hasil belajar intelektual, strategi kognitif, sikap dan nilai, inovasi verbal, dan hasil belajar motorik. Perubahan tersebut dapat diartikan terjadinya peningkatan dan pengembangan yang lebih baik dibandingkan dengan sebelumnya.

Pembelajaran di sekolah tidak menarik apabila guru dalam mengajar sejarah pada taraf kognitif tingkat rendah. Sebagai akibatnya siswa diminta menghafal fakta-fakta pada buku-buku yang dijadikan acuan dalam mengajarnya. Muara dari pelaksanaan pembelajaran seperti itu adalah prestasi belajar siswa rendah dan siswa kurang memahami sejarah bangsanya sendiri. Agar pembelajaran di sekolah termasuk pembelajaran sejarah menarik, Setyosari (2008:6) berpendapat bahwa penggunaan media pembelajaran merupakan bagian yang sangat menentukan dalam efektifitas dan efisiensi pencapaian tujuan pembelajaran.

Supriyadi (2005:2) mensinyalir perlunya mengusahakan agar pembelajaran sejarah sukses dan salah satu alternatifnya adalah merancang dan melaksanakan pembelajaran dengan menggunakan bantuan media pembelajaran sejarah. Untuk menyajikan pengetahuan sejarah agar lebih bermakna dan tidak sekedar menghafal, diperlukan mediasi pembelajaran untuk membantu siswa menyerap informasi dan menyusun skema dalam benaknya sehingga skema 
tersebut dapat bertahan lama dan tidak mudah lupa. Oleh karena itu, dalam pembelajaran Sejarah selanjutnya akan menggunakan metode mind mappaing.

Fakta di lapangan menunjukkan bahwa banyak siswa Kelas X IIS 1 di SMA Muhammadiyah 3 Yogyakarta bersikap pasif ketika berlangsung pembelajaran di kelas. Selama pembelajaran berlangsung siswa menjadi pendengar yang baik. Ketika guru mejelaskan materi pelajaran kebanyakan mereka diam. Demikianpun, ketika guru memberikan pertanyaan, sebagian besar siswa diam tanpa komentar. Apalagi ketika guru meminta agar siswa bertanya, merekapun diam. Fakta ini dilatar belakangi karena beberapa hal yaitu: siswa tidak hidup sezaman pada peristiwa sejarah yang terjadi sehingga cenderung menerima apa yang disampaikan guru; siswa kurang membaca buku sejarah sehingga tidak bisa bersikap kritis; dalam menyajikan pelajaran di kelas guru jarang menggunakan metode yang bervariasi sehingga siswa merasa jenuh atau bosan dan kurang berminat dalam mengikuti pembelajaran. Hal tersebut berdampak pada nilai siswa yang kurang maksimal. Oleh karena itu, perlu adanya upaya untuk mengatasi masalah ini dengan cara memperbaiki metode pembelajaran yang dilakukan guru.

Metode yang digunakan oleh peneliti untuk mengatasi masalah tersebut adalah dengan metode mind mapping. Menurut Windura (2008:16) mind mapping adalah suatu teknis grafis yang memungkinkan kita untuk mengeksplo- rasi seluruh kemampuan otak kita untuk keperluan berpikir dan belajar. Dengan penggunaan warna dan simbol-simbol yang menarik akan menciptakan suatu hasil pemetaan pikiran yang baru dan berbeda. Metode ini dianggap efektif oleh peneliti karena memudahkan siswa untuk merangsang berpikir secara kronologis dalam mempelajari sejarah sehingga hasil belajar siswa lebih meningkat. Hal ini didasarkan pada penelitian sebelumnya, yang dilakukan oleh Eny Sulistoningsih dalam penelitiannya yang berjudul "Peningkatan Kemampuan Menulis Narasi dengan Metode Peta Pikiran Pada Siswa Kelas V SDN Karangasem III Surakarta Tahun Ajaran 2010/2011". Terdapat kenaikan prosentase nilai awal untuk siswa kelas V SDN Karangasem III yaitu mencapai 32\%. Kemudian setelah diadakan tindakan, terlihat adanya peningkatan yang cukup signifikan. Prosentase kenaikan nilai siswa pada siklus I yaitu $68 \%$, sementara itu pada siklus II prosentase kenaikan nilai siswa menjadi $84 \%$. Berdasarkan pertimbangan tersebut, maka dalam penelitian tindakan kelas ini, peneliti akan melakukan penilitian dengan judul "Implementasi Mind Mapping Dalam Pembelajaran Sejarah Untuk Meningkatkan Hasil Belajar Siswa Di SMA Muhammadiyah 3 Yogyakarta"

\section{B. METODE PENELITIAN}

Metode penelitian pada dasarnya merupakan cara ilmiah untuk mendapatkan data dengan tujuan dan kegunaan 
tertentu. Dalam penelitian ini peneliti menggunakan jenis Penelitian Tindakan Kelas (PTK). Iskandar (2012:21) menjelaskan bahwa penelitian tindakan kelas adalah suatu kegiatan ilmiah yang dilakukan secara rasional, sistematis dan empiris reflektif terhadap berbagai tindakan yang dilakukan oleh guru atau dosen, kolaborasi yang sekaligus sebagai peneliti, sejak disusunnya suatu perencanaan sampai penilaian terhadap tindakan nyata di dalam kelas yang berupa kegiatan belajar mengajar untuk memperbaiki dan meningkatkan kondisi pembelajaran yang dilakukan. Mengacu pada pengertian tersebut, maka peneliti berkolaboratif dengan menggabungkan beberapa pihak, yaitu kolaborator, peserta didik, dan peneliti sendiri.

Penelitian ini merupakan Penelitian Tindakan Kelas dengan menggunakan 2 siklus. Menurut Mohamad Asrori (2007: 6), Penelitian Tindakan Kelas merupakan suatu bentuk penelitian yang bersifat reflektif dengan melakukan tindakan-tindakan tertentu untuk memperbaiki dan meningkatkan praktik pembelajaran di kelas secara lebih berkualitas sehingga siswa dapat memperoleh hasil belajar yang lebih baik.

Dalam penelitian tindakan kelas ini, peneliti menggunakan bentuk kolaborasi yaitu bekerja sama dengan teman sejawat dalam memikirkan dan menemukan permasalahan yang akan diteliti melalui penelitian tindakan kelas ini. Dengan demikian, peneliti dan teman sejawat dapat saling belajar dan saling mengisi terhadap proses peningkatan profesionalisme. Pelaksanaan penelitian tindakan kelas ini, peneliti memilih model yang dikemukakan oleh Kemmis dan Mc Taggart (Suharsimi Arikunto, 2007: 16) yang terdiri dari: 1) perencanaan (planning); 2) aksi atau tindakan (acting); 3) observasi (obbserving); dan 4) refleksi (reflecting). Keempat komponen tersebut merupakan langkahlangkah sebuah siklus sehingga Kemmis dan Mc Taggart (Suyadi, 2013: 78) menggabungkan tindakan dan pengamatan ini kemudian dijadikan sebagai dasar langkah berikutnya, yaitu refleksikemudian disusun sebuahmodifikasi dalam bentuk tindakan dan pengamatan lagi, begitu juga seterusnya. Model kegiatan penelitian tindakan kelas menurut Kemmis dan Mc Taggart disajikan dalam gambar1 berikut.

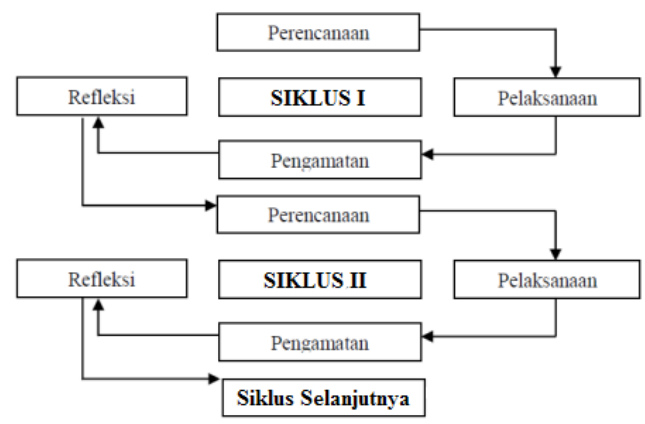

Gambar 1. 1 Model Spiral dari Kemmis dan Taggart

Hubungan antara tahapan-tahapan dalam penelitian dijlaskan dalam gambar 2 . 
Sri Mawanto - Implementasi Mind Mapping dalam Pembelajaran Sejarah untuk Meningkatkan Hasil ....

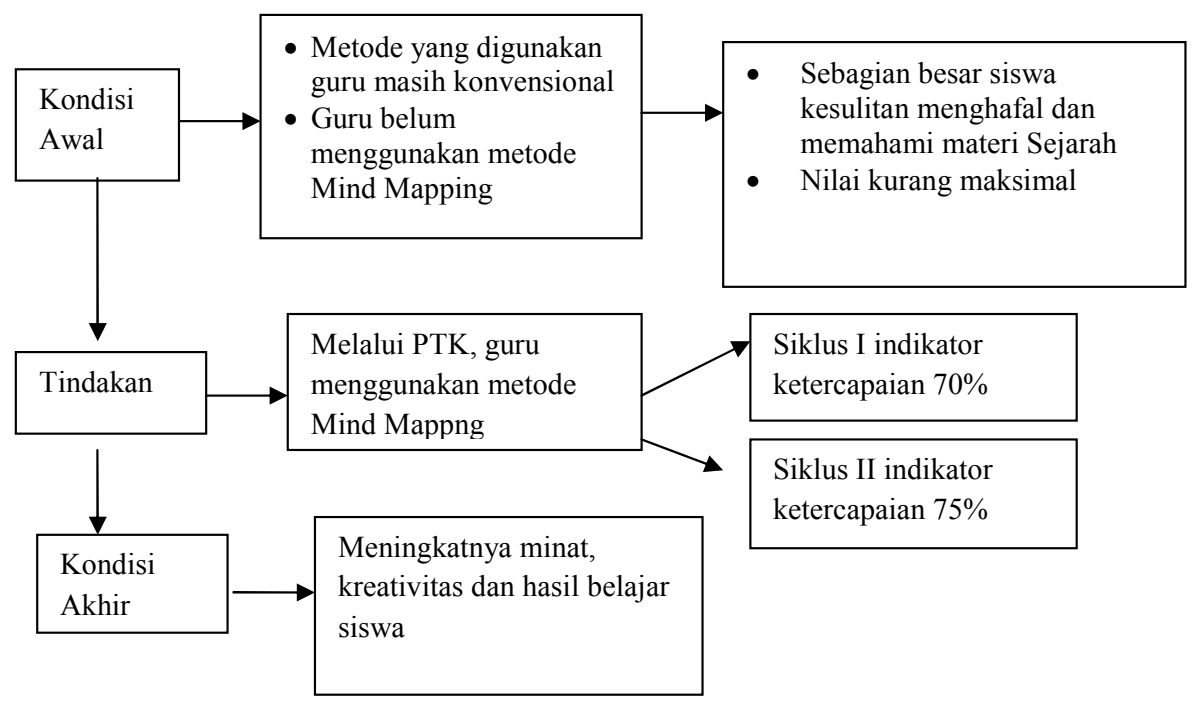

Gambar 2. Alur Penelitian Tindakan Kelas pada setiap siklus

Teknik yang digunakan untuk mengumpulkan data dalam penelitian tindakan kelas ini adalah sebagai berikut:

1. Observasi

Observasi ini dilakukan oleh pen- eliti secara langsung selaku guru mata pelajaran Sejarah dengan ditemani seorang kolaborator. Untuk melaksanakan teknik observasi ini, maka peneliti dan kolaborator menyusun tabel kriteria observasi bagi siswa sebagai berikut:

Tabel 1. Kriteria Observasi Siswa

\begin{tabular}{|c|c|c|}
\hline $\mathrm{NO}$ & VARIABEL & INDIKATOR \\
\hline \multirow[t]{4}{*}{1} & \multirow[t]{4}{*}{ Kedisiplinan Siswa } & $\begin{array}{l}\text { 1. Siswa tepat masuk kelas sebelum pelajaran di } \\
\text { mulai }\end{array}$ \\
\hline & & $\begin{array}{l}\text { 2. Siswa memberikan salam pada guru sebelum pe- } \\
\text { lajaran di mulai }\end{array}$ \\
\hline & & 3. Siswa berdo'a sebelum pelajaran di mulai \\
\hline & & 4. Guru menyampaikan lama pembelajaran \\
\hline \multirow[t]{4}{*}{2} & \multirow{4}{*}{$\begin{array}{l}\text { Kesiapan siswa me- } \\
\text { nerima pelajaran }\end{array}$} & 1. Siswa menyiapkan buku tulis \\
\hline & & 2. Siswa menyiapkan alat-alat tulis \\
\hline & & 3. Siswa menyiapkan buku pelajaran \\
\hline & & $\begin{array}{l}\text { 4. Siswa menyiapkan alat -alat yang di gunakan } \\
\text { untuk berdiskusi }\end{array}$ \\
\hline
\end{tabular}




\begin{tabular}{|c|c|c|}
\hline $\mathrm{NO}$ & VARIABEL & INDIKATOR \\
\hline \multirow[t]{4}{*}{3} & \multirow[t]{4}{*}{ Keaktifan Siswa } & $\begin{array}{l}\text { 1. Siswa mengikuti proses pembelajaran dari awal } \\
\text { sampai akhir dengan baik }\end{array}$ \\
\hline & & 2. Siswa berani mengemukakan pendapat \\
\hline & & 3. Siswa berani bertanya bila mengalami kesulitan \\
\hline & & 4. Siswa berinteraksi aktif dengan kelompok diskusi \\
\hline \multirow[t]{4}{*}{4} & \multirow{4}{*}{$\begin{array}{l}\text { Kemampuan siswa } \\
\text { menjawab pertany- } \\
\text { aan dalam diskusi }\end{array}$} & 1. Siswa menjawab pertanyaan sesuai pertanyaan \\
\hline & & 2. Siswa menjawab pertanyaan secara logis \\
\hline & & 3. Siswa menjawab pertanyaan secara lengkap \\
\hline & & 4. Siswa mampu mengikuti pelajaran dengan baik \\
\hline
\end{tabular}

2. Dokumentasi

Kajian dokumen digunakan untuk memperoleh berbagai arsip atau data berupa kurikulum, Rencana Pelaksanaan Pembelajaran, hasil pekerjaan mind mapping siswa, dan nama responden penelitian pada siswa kelas X IIS 1 SMA Muhammadiyah 3 Yogyakarta. Dokumentasi dapat juga berupa foto dan video saat proses pembelajaran berlangsung ataupun segala macam tulisan yang terkait dengan masalah penelitian.

\section{Tes}

Tes yang diberikan kepada siswa kelas X IIS 1 SMA Muhammadiyah 3 Yogyakarta berupa tes uraian dalam bentuk Essay. Waktu pelaksanan tes dilakukan pada awal pertemuan sebagai pre test, kemudian diadakan post test padi setiap akhir pelaksanaan siklus. Pemberian tes ini dimaksudkan untuk mengetahui seberapa jauh hasil yang diperoleh siswa kelas X IIS 1 SMA Muhammadiyah 3 Yogyakarta setelah kegaitan pemberian tindakan mulai awal sampai akhir.

Setelah data yang dibutuhkan oleh peneliti terkumpul, selanjutnya dilakukan teknik analisis data. Teknik analisis data ini digunakan untuk menganalisis seberapa besar tingkat kenaikan hasil belajar pada siswa. Sedangkan untuk menentukan prosentase keberhasilan tindakan didasarkan pada data skor yang diperoleh dari hasil observasi dengan menggunakan rumus prosentase sebagai berikut:

\section{$\frac{\text { Jumlah Skor }}{\text { Skor maksimal }} \times 100 \%$}

Dari perolehan nilai yang didapat oleh siswa, kemudian diadakan analisis mengenai penguasaan materi. Hal ini dilakukan untuk acuan peneliti dalam menerapkan metode mind mapping selanjutnya. Adapun pedoman yang dilakukan oleh peneliti adalah sebagai berikut: 
Sri Mawanto - Implementasi Mind Mapping dalam Pembelajaran Sejarah untuk Meningkatkan Hasil ....

Tabel 2. Tingkat Penguasaan

\begin{tabular}{|c|c|c|c|}
\hline $\begin{array}{c}\text { Tingkat Pengu- } \\
\text { asaan }\end{array}$ & $\begin{array}{c}\text { Nilai } \\
\text { Huruf }\end{array}$ & Bobot & Predikat \\
\hline $86-100 \%$ & $\mathrm{~A}$ & 4 & $\begin{array}{c}\text { Sangat } \\
\text { baik }\end{array}$ \\
\hline $76-85 \%$ & $\mathrm{~B}$ & 3 & Baik \\
\hline $60-75 \%$ & $\mathrm{C}$ & 2 & Cukup \\
\hline$<59 \%$ & $\mathrm{D}$ & 1 & Kurang \\
\hline
\end{tabular}

Menurut Mulyasa (2006:101-102) mengatakan bahwa kualitas pembelajaran dapat dilihat dari sesi proses dan dari segi hasil. Dari segi proses, pembelajran dikatakan berhasil dan berkualitas, apabila seluruh atau setidak-tidaknya sebagian besar $75 \%$ peserta didik terlibat secara aktif baik fisik maupun mental dalam proses pembelajaran. Disamping itu siswa juga harus menunjukkan kegairahan belajar yang tinggi, semangat belajar yang besar dan rasa percaya diri yang tinggi. Sedangkan dari segi hasil, proses pembelajaran dikatakan berhasil apabila terjadi perubahan tingkah laku yang positif pada diri peserta didik seluruhnya, atau sekurang-kurangnya $75 \%$. Indikator prestasi belajar dari penelitian ini adalah jika $75 \%$ dari siswa telah mencapai nilai minimal 71. Penetapan nilai 71 didasarkan nilai KKM mata pelajaran Sejarah di SMA Muhammadiyah 3 Yogyakarta.

\section{HASIL PENELITIAN DAN PEMBAHASAN}

Hasil penelitian diuraikan dalam tahapan yang berupa siklus pembelajaran yang dilakukan dalam proses belajar mengajar di kelas. Dalam penelitian inipembelajaran dilakukan dalam dua siklus sebagaimana pemaparan berikut ini:

\section{Kondisi Awal}

Sebelum dilakukan tintakan perbaikan pembelajaran, terlebih dahulu diadakan pendataan atau pencatatan hal-hal yang dijadikan dasar dari tindakan. Dalam hal ini digunakan perbaikan pembelajaran melalui siklus dalam penelitian tindakan kelas. Sebelum dilakukan perbaikan pembelajaran, guru melakukan kegiatan awal berupa siswa membaca secara mandiri materi yang telah ditentukan. Sebagaimana sudah diungkapkan pada rumusan masalah yang diangkat pada penelitian tindakan kelas ini yaitu untuk mengetahui kenaikan hasil belajar siswa, maka dilakukan pengukuran dengan cara siswa mengerjakan berbagai bentuk soal terkait dengan materi Sejarah pemerintahan kerajaan bercorak Islam. Soal ini sebagai pre test.

Hasil pretes menunjukkan bahwa dari 36 siswa, satu siswa mendapat nilai 80,6 siswa mendapat 70, 29 siswa dibawah 70. Berarti dapat disimpulkan bahwa sebanyak 29 siswa belum mencapai nilai KKM. Untuk menyikapi terhadap 29 siswa ini maka peneliti meminta siswa untuk membuat rangkuman tentang sejarah Pemerintahan Kerajaan Islam di Indonesia dan dikumpulkan pada pertemuan selanjutnya. Selanjutnya guru menjelaskan tentang mind mapping. kemudian diperkenalkan metode mind mapping. Di sini dijelaskan tentang 
apa itu metode mind mapping, kegunaannya, aturan-aturannya serta cara pembuatannya. Semua siswa nampak tertarik dan memperhatikan ketika metode baru ini diperkenalkan. Mungkin karena sebelumnya belum pernah diperkenalkan suatu metode, atau karena ada kolaborator atau karena metodenya memang menarik bagi mereka. Yang penting, pada langkah pertama ini sudah kelihatan ada perubahan yang positif pada siswa.

\section{Siklus 1}

a. Perencanaan

Pada perencanaan siklus I, peneliti merencanakan 3 kali pertemuan di kelas X IIS 1. Materi yang dipilih adalah adalah tentang Sejarah Pemerintahan Kerajaan bercorak Islam di Indonesia. Adapun jadwal beserta kegiatan yang direncanakan oleh peneliti adalah sebagai berikut:

Tabel 3 Perencanaan Siklus 1

\begin{tabular}{|c|c|c|c|c|}
\hline No & Tanggal & $\mathbf{J P}$ & Kegiatan Pembelajaran & Keterangan \\
\hline 1 & 26-1-2018 & $2 \mathrm{JP}$ & $\begin{array}{l}\text { 1. } \text { Mengisi Angket } \\
\text { 2. } \text { Pre Test } \\
\text { 3. Pengenalan mind mapping } \\
\text { 4. }\end{array}$ & Klasikal \\
\hline 2 & 29-1-2018 & $2 \mathrm{JP}$ & Pelaksanaan Mind Mapping & Klasikal \\
\hline 3 & $2-2-2018$ & $2 \mathrm{JP}$ & $\begin{array}{l}\text { Presentasi masing-masing } \\
\text { Kelompok }\end{array}$ & \\
\hline 3 & $5-2-2018$ & $2 \mathrm{JP}$ & Post test & Test tertulis \\
\hline
\end{tabular}

b. Tindakan

Pertemuan pertama dilaksanakan pada tanggal 26 Februari 2018. Pertemuan ini diawali dengan pemberian motivasi, apersepsi dan penyampaian tujuan belajar hari itu. Kemudian sebelum tindakan dilaksanakan, kepada siswa dibagikan angket yang harus diisi dengan jujur. Agar supaya benarbenar jujur, identitas siswa tidak perlu dicantumkan. Dengan asumsi, kalau nama siswa dicantumkan, siswa akan kurang leluasa dalam mengisi angket, karena takut akan mempengaruhi nilai Sejarah mereka. Setelah pengisian ang- ket selesai, lalu dikumpulkan. Ketika menyerahkan angket, kebanyakan siswa memilih diletakkan di bawah, supaya tidak kelihatan. Hasil angket sebelum tindakan dilaksanakan : dari 36 siswa, ada 3 siswa yang sangat berminat terhadap mata pelajaran Sejarah dengan skor 33, 34 dan 35. Yang berminat ada 20 siswa, dengan skor mulai dari 25 sampai dengan 32. Yang kurang berminat ada 12 siswa dengan skor 21, 22, dan 23. Dan yang tidak berminat ada 1 siswa dengan skor 16. Setelah angket dikumpulkan, lalu dibagikan soal pretes dengan diberikan penjelasan seperlu- 
nya. Topik dalam soal tentang Sejarah Pemerintahan Kerajaan Islam.

Hasil pretes adalah sebagai berikut : dari 36 siswa, satu siswa mendapat nilai 80,6 siswa mendapat 70, 29 siswa dibawah 70. Berarti dapat disimpulkan bahwa sebanyak 29 siswa belum mencapai nilai KKM. Untuk menyikapi terhadap 29 siswa ini maka peneliti meminta siswa untuk membuat rangkuman tentang sejarah Pemerintahan Kerajaan Islam di Indonesia dan dikumpulkan pada pertemuan selanjutnya. Selanjutnya guru menjelaskan tentang mind mapping. kemudian diperkenalkan metode mind mapping. Di sini dijelaskan tentang apa itu metode mind mapping, kegunaannya, aturan-aturannya serta cara pembuatannya. Semua siswa nampak tertarik dan memperhatikan ketika metode baru ini diperkenalkan. Mungkin karena sebelumnya belum pernah diperkenalkan suatu metode, atau karena ada kolaborator atau karena metodenya memang menarik bagi mereka. Yang penting, pada langkah pertama ini sudah kelihatan ada perubahan yang positif pada siswa.

Setelah diperkenalkan metode mind mapping, kemudian peneliti membagi kelompok. Karena ada 36 siswa maka dibagi 6 kelompok dengan masingmasing siswa ada 6 anak. Setelah dibagi kelompoknya, kemudian peneliti meminta kepada para siswa untuk menyiapkan pertemuan selanjutnya dengan membawa crayon, pensil warna, kertas A3/manila, spidol dan sketsa gambar. Pertemuan ketiga pada tang- gal 29 Januari 2018, peneliti meminta kepada para siswa untuk duduk sesuai kelompoknya dan kemudian melaksanakan tugasnya yaitu membuat mind mapping. Mind Mapping ini kemudian dielaborasikan dalam sebuah diskusi kelas untuk menigkatkan pemahaman siswa. Berdasarkan hasil penelitian yang dilakukan oleh peneliti, pelaksanaan aktivitas kelompok dalam pembelajaran dengan metode mind mapping masih ada yang nilainya kurang dari KKM. Hal ini berarti bahwa pelaksanaan siklus 1 belum dikatakan berhasil. Ada 4 kelompok yang memiliki nilai kurang 75 yaitu kelompok 3 nilai rata-rata 61,83 ; kelompok 4 nilai rata-rata 67,83 ; kelompok 5 nilai rata-rata 68,93 dan kelompok 6 nilai rata-rata 68 . Dari data tersebut nilai rata-rata kelompok 68,79 . Hal ini masih jauh dari nilai KKM.Dari analisis peneliti dengan kolaborator hal ini disebabkan karena persebaran anggota kelompok yang memiliki kemampuan tidak merata. Selain itu pada siklus 1 tidak ada hand out yang menjadi panduan untuk melaksanakan aktivitas mind mappimg. Oleh karena itu, pada siklus selanjutnya akan ada persebaran kelompok secara merata dan juga ada hand out dari guru.

Sedangkan untuk nilai kognitif individu pada siklus 1 kelas X IIS 1 nilai di bawah KKM sebanyak 28 siswa yang belum tuntas. Berarti hanya 8 siswa yang tuntas dengan persentase ketuntasan sebanyak 22,22\%. Setelah dikenai tindakan pada siklus 2 dengan menggunakan metode mind mapping 
maka jumlah siswa yang di bawah KKM mengalami penurunan dari 28 siswa menjadi 11 siswa. Sedangkan nilai yang diatas KKM mengalami kenaikan dari 8 siswa menjadi 25 siswa dengan persentase ketuntasasan sebanyak 69,44 $\%$. Dari data tersebut dapat diketahui bahwa kenaikan nilai kognitif sebesar $69,44 \%-22,22 \%=47,22 \%$.

\section{c. Observasi}

Observasi dilakukan oleh kolaborator (Ibu Yuli Astuti, S.Pd) dan peneliti sendiri berdasarkan Lembar Pengamatan yang telah disiapkan. Observasi pertama dilaksanakan pada tanggal 29 Januari 2018 yang bertempat di ruang kelas X IIS 1 SMA Muhammadiyah 3 Yogyakarta. Dalam observasi pertama dapat diuraikan secara umum bahwa suasana siswa dalam kelas sangat baik dan tertib. Sebagian besar siswa nampak tertarik dengan metode, materi dan cara penyampaian yang dilakukan oleh peneliti. Selain itu, siswa juga nampak lebih senang belajar dalam kelompok. Berdasarkan catatan yang dituliskan oleh kolaborator dapat diuraikan bahwa dalam pelaksanaan penelitian ini, peneliti sudah melaksanakan pembelajaran sesuai dengan RPP, adanya usaha untuk menarik minat siswa dengan cara melibatkan banyak siswa dalam menjelaskan materi, adanya keadanyteraturan dalam membentuk kelompok, serta adanya usaha untuk memunculkan kreatifitas siswa dengan membebaskan siswa dalam memberi nama kelompok, memilih kertas dan ukurannya, serta pewarnaan dalam pembuatan mind mapping.

\section{d. Refleksi}

Berdasarkan hasil observasi yang diperoleh selama pelaksanaan tindakan Siklus 1, ada beberapa hal penting yang perlu diperhatikan dan diperbaiki untuk rencana tindakan pada siklus berikutnya. Adapun yang perlu diperhatikan peneliti adalah masalah pembagian kelompok. Pembagian kelompok perlu ditinjau ulang dalam pendistribusian siswa. Untuk mendapatkan hasil yang maksimal, setiap kelompok harus ada siswa yang terampil di bidangnya sesuai dengan kemampuan, diantaranya keterampilan menggambar dan berbicara.

\section{Siklus 2}

a. Perencanaan

Perencanaan Siklus 2 akan dilaksanakan sebanyak 2 kali pertemuan yaitu tanggal 12 dan 19 Februari 2018 dengan alokasi setiap pertemuan selama 2 x 45 menit. Pada dasarnya proses pembelajaran siklus 2 sama seperti siklus 1. Materi yang diajarkannyapun sama yaitu masa pemerintahan Kerajaan Islam di Indonesia.

b. Pelaksanaan

Pada mind mapping siklus kedua ini para siswa lebih tertata dan lebih tenang. Gambar yang dibuat pun juga lebih menarik. Pertemuan kedua dilaksanakan pada tanggal 19 Februari 2018 dengan mempresentasikan hasil diskusinya. Ketika mempresentasikan hasil mind mapping, para siswa lebih menguasai 
materi, lebih tertata dan lebih percaya diri. Setelah pelaksanaan kegiatan ini dilakukan Post Test mengenai aktivitas kegiatan kelompok.

c. Observasi

Hasil perolehan aktivitas kelompok dalam mengikuti pelaksanaan pembelajaran dengan metode mind mapping mengalami kenaikan rata-rata pada kreativitas siswa. Jika dibandingkan pada siklus 1 maka dapat diperoleh kenaikan sebesar 81,71 - 68,79 = 12,92\%. Pada siklus 1 nilai di bawah KKM sebanyak 11 siswa yang belum tuntas. Berarti 25 siswa yang tuntas dengan persentase ketuntasan sebanyak 69,44\%. Setelah dikenai tindakan pada siklus 2 dengan menggunakan metode mind mapping maka jumlah siswa yang di bawah KKM mengalami penurunan dari 11 siswa menjadi 4 siswa. Sedangkan nilai yang diatas KKM mengalami kenaikan dari 25 siswa menjadi 32 siswa dengan persentase ketuntassan sebanyak 88,89 $\%$. Dari data tersebut dapat diketahui bahwa kenaikan nilai kognitif sebesar $88,89 \%-69,44 \%=19,45 \%$. Hal ini berarti kenaikan siklus 2 sebesar $88,89 \%$. Dari data tersebut apabila digambarkan dalam sebuah grafik sebagai berikut:

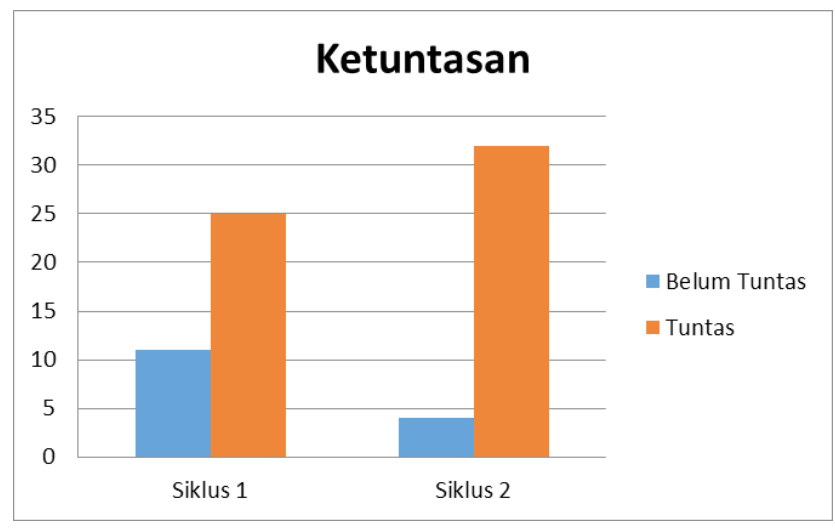

Gambar 2. Perbandingan Ketuntasan Siswa Siklus 1 dengan siklus 2

\section{d. Refleksi}

Metode ini sangat efektif untuk mengajarkan materi Sejarah. Namun, berdasarkan pengamatan selama pembelajaran, siswa memerlukan waktu lama untuk menyelesaikan mind mapping.

\section{KESIMPULAN}

Berdasarkan hasil Penelitian Tindakan Kelas (PTK) dan pembahasan dapat disimpulkan sebagai berikut.

Pertama, metode pembelajaran Mind Mapping dapat diimplementasikan untuk meningkatkan hasil belajar pada mata pelajaran sejarah.Terlihat dari aktivitas siswa yang dilakukan 
pada saat pembelajaran berlangsung. Dalam pelaksanaan proses pembelajaran Mind Mapping, siswa sangat antusias untuk mengikuti arahan yang disampaikan oleh guru. Siswa dapat mengembangkan kreativitasnya dalam sebuah gambar yang menarik dengan perpaduan warna yang kontras. Selain itu, siswa juga dapat lebih memahami materi pembelajaran Sejarah. Hal ini dapat dilihat oleh peneliti, ketika siswa mempresentasikan hasil Mind Mapping di depan kelas.

Kedua, model pembelajaran Mind Mapping dapat meningkatkan hasil belajar pada materi sjarah Pemerintahan Kerajaan bercorak Islam di Indonesia bagi siswa X IIS 1 SMA Muhammadiyah 3 Yogyakarta. Penerapan model pembelajaran mind mapping dalam pembelajaran sejarah dapat meningkatkan hasil belajar siswa kelas X IIS 1 SMA Muhammadiyah 3 Yogyakarta. Peningkatan hasil belajar dibuktikan dengan adanya peningkatan jumlah siswa yang memenuhi nilai KKM yaitu 75 pada setiap siklusnya dan telah memenuhi indikator kinerja yang ditargetkan pada tahap pratindakan, siklus I dan siklus II. Pada pra siklus nilai di bawah KKM sebanyak 28 siswa yang belum tuntas. Berarti hanya 8 siswa yang tuntas dengan persentase ketuntasan sebanyak $22,22 \%$. Setelah dikenai tindakan pada siklus 2 dengan menggunakan metode mind mapping maka jumlah siswa yang di bawah KKM mengalami penurunan dari 28 siswa menjadi 11 siswa. Sedangkan nilai yang diatas KKM mengalami kenaikan dari 8 siswa menjadi 25 siswa dengan persentase ketuntasan sebanyak $69,44 \%$. Setelah dikenai tindakan pada siklus 2 dengan menggunakan metode mind mapping maka jumlah siswa yang di bawah KKM mengalami penurunan dari 11 siswa menjadi 4 siswa. Sedangkan nilai yang diatas KKM mengalami kenaikan dari 25 siswa menjadi 32 siswa dengan persentase ketuntasasan sebanyak $88,89 \%$. Ketuntasan hasil belajar siswa ini telah melampaui target penelitian yaitu sebesar $\geq 75 \%$.

Beberapa saran yang dapat peneliti sampaikan berdasarkan hasil Penelitian Tindakan Kelas (PTK) ini dalam rangka membangun semangat dan keprofesionalan dalam pembelajaran Sejarah kelas $\mathrm{X}$ adalah sebagai berikut: bagi guru, hendaknya selalu berkreasi untuk selalu mengembangkan keprofesionalannya dengan cara giat melakukan penelitian terutama Penelitian Tindakan Kelas (PTK) dan bagi peneliti lain yang tertarik dengan Penelitian Tindakan Kelas (PTK) ini dapat mencari model pembelajaran dan media pembelajaran yang lain guna meningkatkan hasil pembelajaran matematika di tingkat SMA supaya lebih baik dari sebelumnya. Sehingga, peneliti lain dapat menghasilkan PTK lain yang lebih baik.

\section{E. DAFTAR PUSTAKA}

Aini, Annisa; Andayani, Andayani; Anindyarini, Atikah.2012.Metode Mind Mapping Untuk Meningkatkan Keterampilan Berbicara 
Sri Mawanto - Implementasi Mind Mapping dalam Pembelajaran Sejarah untuk Meningkatkan Hasil ....

Siswa Sekolah Dasar.Basastra Vol 1, No 1

Astuty, Dewi Tri.2013.The Effectiveness Of Using Mind Mapping Technique In Teaching Descriptive Text For Improving Writing Ability Of Tenth Grade Students Of Senior High School Of Sma Widya Kutoarjo In Academic Year 2012/2013.SCRIPTA - Pendidikan Bahasa Inggris Vol 1, No 2

Atma Dwi Desyanti, Farida; Susanah, Susanah.2013.Penerapan Metode Pembelajaran Mind Mapping Pada Materi Statistika.MATHEdunesa Vol 2, No 1

Buzan, Tony. 2005. Buku Pintar Mind Maps. Jakarta : Gramedia.

Depdiknas.2006. Kurikulum Tingkat Satuan Pendidikan. Jakarta: Depdiknas

Desy A, Lutgardis; , Fahri.2013.The Implementation Of Mind Mapping In Teaching Writing Narrative Text Fot Tenth Grades Of Sman 18 Surabaya.Retain Vol 1, No 3

Kusmintayu, Norma; Suwandi, Sarwiji; Anindyarini, Atikah.2012.Penerapan Metode Mind Mapping Untuk Meningkatkan Keterampilan Berbicara Pada Siswa Sekolah Menengah Pertama.Basastra Vol 1, No 1

Lestari, Weni Arianingtyas.2012. Uji Penggunaan Mind Mapping Untuk Meningkatkan Hasil Belajar Pada Siswa MTs Negeri Purworejo.
RADIASI. Pendidikan Fisika Vol 1, No 1 (2012): Vol. 1. No.1. September 2012 page. $76-79$

Modeong, Fira Rapianty; Tulandi, Djeli; Wagania, Hans. 2013. Efektivitas Pembelajaran Fisika Berbasis Software Mind Mapping Dalam Meningkatkan Hasil Belajar Siswa Kelas X SMA Negeri 2 Manado. JSME MIPA UNIMA Vol 1, No 3

MP, Feriana Solikati; Santosa, Slamet; Ariyanto, Joko. 2012.Pengaruh Strategi Pembelajaran Card Sort Disertai Mind Mapping Hasil Belajar Biologi Siswa Sma Banyudono Tahun Pelajaran 2011/2012. Pendidikan Biologi Vol 4, No 2

Moleong, Lexy J. 2002. Metodologi Penelitian Kualitatif. Bandung: Remaja Rosda Karya

Mudjijo. 1995. Tes Hasil Belajar. Jakarta: Bumi Aksara

Mulyasa, E. 2007. Menjadi Guru Profesional Menciptakan Pembelajaran Kreatif dan Menyenangkan. Bandung: Remaja Rosda Karya

Prabowo, Yudha Novisiyono.2013. Penerapan Media Mind Mapping Untuk Meningkatkan Prestasi Relajar Siswa Kelas XI Pada Kompetensi Dasar Memperbaiki Sistem Pengapian Di SMKN $1 \mathrm{Ka}$ nor Bojonegoro.Jurnal Pendidikan Teknik Mesin Volume 01, Nomor 03, Tahun 2013 page. 56-62

Purwanto, Nangim. Evaluasi Hasil Be- 
lajar. Yogyakarta: Pustaka Pelajar Riza Nur Maulida, Fatma Riza Nur.2013.Penerapan Mind Mapping Sebagai Strategi Belajar Ipa Terpadu Pokok Bahasan Mata Dalam Meningkatkan Hasil Belajar Siswa SMP.Program Studi Pendidikan Sains Fmipa Unesa). Pendidikan Sains Vol 1, No 02

S, Rosmaini; Wulandari, Yessi. 2011. Penerapan Teknik Mind Mapping Dalam Strategi Quantum Learning Untuk Meningkatkan Motivasi Dan Hasil Belajar Biologi Siswa Kelas Xi Ipa2 Sma Nurul Falah Pekanbaru Ta. 2009/2010. Biogenesis.Jurnal Pendidikan Sains Dan Biologi Vol 7, No 02

Sanjaya,Wina. 2009. Penelitian Tindakan Kelas. Jakarta: Pranata Media

Santosa. Metode Penelitian. Yogyakarta: Pustaka Pelajar

Sefrikadarismawan, ; Yustanti, Wiyli.2012.Rancang Bangun Media Pembelajaran Statistika Berbasis Mind Mapping. Jurnal Teknik Elektro Vol 1, No 1
Slameto.2003. Belajar dan FaktorFaktor yang Mempengaruhinya. Jakarta: Rineka Cipta

Supriyadi. 2005. Membangun Bangsa Melalui Pendidikan. Bandung: Remaja Rosda Karya

Sutanto, Windura. Buku Pintar Mind Map untuk Anak. Jakarta: Gramedia Pustaka Utama

Suyadi. 2013. Panduan Guru Profesional Penelitian Tindakan Kelas (PTK) dan Tindakan Sekolah (PTS). Yogyakarta: Andi Offset

Wahyu Purwaningrum, Sri. 2013. Penggunaan Metode Peta Pikiran (Mind Mapping) Untuk Meningkatkankemampuan Menulis Narasi Siswa Sekolah Menengah Pertama.Basastra Vol 2, No 1

Zaqiyyatun Nafsi, Anis Zaqiyyatun.2013.Penerapan Model Direct Instruction Dengan Teknik Mind Mapping Pada Tema Perkaratan Logam Besi Untuk Meningkatkan Hasil Belajar Siswa. Pendidikan Sains Vol 1, No 02 (2013) 